\title{
NEMATODA PARASIT TUMBUHAN DOMINAN PADA BIBIT DAN TANAMAN KOPI ROBUSTA (C. canephora var robusta) MUDA DI KABUPATEN TANGGAMUS, LAMPUNG
}

\author{
I Gede Swibawa1), Nur Yasin ${ }^{1)}$, Titik Nur Aeny') Sari Dewi ${ }^{2)}$ \\ 1. Dosen Jurusan Agroteknologi, Fakultas Pertanian Universitas Lampung \\ 2. Mahasiswa Jurusan Agroteknologi Fakultas Pertanian Universitas Lampung \\ Jln. Prof. Dr. Soemantri Brojonegoro No. 1, Bandar Lampung 35145 \\ E-mail: igswibawa@yahoo.com
}

\begin{abstract}
ABSTRAK
Penelitian ini bertujuan untuk mengetahui genus nematoda parasit tumbuhan yang dominan pada bibit dan tanaman kopi robusta (C. canephora var robusta) muda di Kabupaten Tanggamus dan mengetahui kelimpahan nematoda parasit tumbuhan yang dominan dan tingkat kerusakan tanaman akibat serangan nematoda pada bibit dan tanaman kopi robusta (C. canephora var robusta) muda di Kabupaten Tanggamus. Pengambilan sampel dilakukan di kebun pembibitan kopi Edufarm PT Nestle Indonesia di Kecamatan Talang Padang dan kebun tanaman kopi robusta muda milik petani binaan PT Nestle Indonesia di Kecamatan Ulu Belu, Air Naningan, Sumberejo, dan Pulau Panggung. Proses laboratorium dilakukan di Laboratorium Ilmu Hama Tumbuhan Fakultas Pertanian Universitas Lampung. Penelitian ini dilaksanakan pada bulan Februari - Agustus 2017 menggunakan metode survai. Datakomunitas nematoda dianalisis menggunakan Prominance Value (PV). Kelimpahan seluruh nematoda dari tanah dan akar, kelimpahan genus nematoda parasit tumbuhan yang dominan dari akar dan tanah dan intensitas kerusakan akar dianalisis ragam dan pemisahan nilai tengah diuji Beda Nyata Terkecil (BNT) pada taraf nyata 5\%. Hasil penelitian menunjukkan bahwa ditemukan 38 genus nematoda yang terdiri dari 16 genus nematoda parasit tumbuhan dan 22 genus nematoda hidup bebas, lima genus nematoda parasit tumbuhan yang dominan yaitu Pratylenchus, Radopholus, Rotylenchulus, Helicotylenchus, dan Ditylenchus. Kelimpahan Pratylenchus pada bibit dan kopi robusta muda yaitu 13 - 190 individu/300 cc tanah dan 321 individu/10 g akar di kebun bibit. Intensitas kerusakan tanaman mutlak (keterjadian) dan kerusakan tanaman relatif(keparahan) bibit yaitu $27 \%$ dan $11,8 \%$ dengan intensitas kerusakan akar 69,20\%. Intensitas kerusakan tanaman mutlak (keterjadian) dan kerusakan tanaman relatif (keparahan) tanaman kopi muda berkisar $32-61 \%$ dan $19-24 \%$ dengan intensitas kerusakan akar berkisar $35-48,17 \%$.
\end{abstract}

Kata kunci: kopi robusta, nematoda, Pratylenchus, Radopholus

\section{PENDAHULUAN}

Pada tahun 2016 produksi kopi di Indonesia yaitu 639.305 ton, sedangkan produksi kopi di Lampung mencapai 110.354 ton (Direktorat Jenderal Perkebunan, 2016). Dari total produksi kopi di
Lampung, Tanggamus menyumbang produksi kopi robusta sebesar 36.520 ton dengan rata-rata produktivitas 0,82 ton/ha (Badan Pusat Statistik Provinsi Lampung, 2013). Produktivitas kopi robusta di Tanggamus tersebut masih lebih rendah jika 
dibandingkan dengan produktivitas potensial varietas/ klon unggul kopi robusta yang mencapai 1,2 ton/ha (Keputusan Menteri Pertanian, 2004).

Salah satu penyebab rendahnya produksi kopi adalah serangan nematoda parasit tumbuhan. Menurut Campos \& Villain (2005), terdapat beberapa genus nematoda yang sering menyebabkan masalah serius pada budidaya tanaman kopi yaitu Meloidogyne, Pratylenchus, Rotylenchulus, dan Radopholus. Serangan $P$. coffeae pada tanaman kopi robusta menyebabkan penurunan produksi 28,7\% - 78,4 \% (Wiryadiputra \& Atmawinata, 1998 dalam Mustika, 2010).

Tanggamus merupakan salah satu daerah penghasil kopi terbesar dan terluas di Lampung. Peremajaan tanaman kopi sudah dilakukan oleh petani setempat pada periode Januari - Maret 2014. Bibitbibit yang digunakan untuk peremajaan tanaman kopi berasal dari Pusat Penelitian Kopi dan Kakao Indonesia (Puslitkoka) Jember, Jawa Timur (Wiryadiputra, 2014). Bibit-bibit yang diintroduksikan tersebut terdapat kemungkinan membawa nematoda. Menurut Swibawa (2014), Jawa Timur merupakan daerah endemik nematoda parasit tumbuhan $P$. coffeae dan $R$. similis pada tanaman kopi.

Kondisi bibit kopi yang digunakan untuk peremajaan di tempat pembesaran bibit cukup mengkhawatirkan dengan tingkat kematian bibit mencapai $10 \%$. Bibit yang mati menunjukkan gejala daun menguning, layu dari bawah, gugur, dan tanaman mati. Setelah bibit dibongkar keadaan akar membusuk dan media tempat tumbuh bibit sangat lembab. Hasil survai pada bibit sisa tahun 2013 terdapat serangan penyakit Cercospora (Wiryadiputra, 2014). Menurut Wiryadiputra (2014), pada tanaman kopi robusta ( $C$. canephora var. robusta) hasil peremajaan yang ditanam di Tanggamus pada Januari - Maret 2014 terindikasi terserang nematoda. Tanaman hasil peremajaan pada Januari - Maret 2014 termasuk dalam tanaman muda. Evaluasi tersebut dilakukan dengan cara pengamatan secara visual dan analisis di laboratorium. Berdasarkan hasil pengamatan visual di lapangan diestimasi rata rata 4\% tanaman terserang nematoda dan sebanyak 2,4\% positif terinfeksi nematoda $P$. coffeae dan Radopholus spp. (Wiryadiputra, 2014).

Hasil survai yang telah dilakukan tersebuthanya menunjukkan persentase tanaman yang terindikasi mengalami serangan nematoda, sehingga belum diketahui dengan pasti komunitas nematoda yang berasosiasi dengan bibit dan tanaman kopi robusta muda. Penelitian ini untuk mengetahui genus nematoda parasit tumbuhan yang dominan pada bibit dan tanaman kopi robusta (C. canephora var robusta) muda di Kabupaten Tanggamus dan mengetahui kelimpahan nematoda parasit tumbuhan yang dominan dan mengetahui tingkat kerusakan tanaman akibat serangan nematoda pada bibit dan tanaman kopi robusta $(C$. canephora var robusta) muda di Kabupaten Tanggamus.

\section{METODE PENELITIAN}

Penelitian dilakukan di kebun pembibitan kopi Edufarm PT Nestle Indonesia di Kecamatan Talang 
Padang dan kebun tanaman kopi robusta muda milik petani binaan PT Nestle Indonesia di Kecamatan Ulu Belu, Air Naningan, Sumberejo, dan Pulau Panggung. Proses laboratorium dilakukan di Laboratorium Ilmu Hama Tumbuhan Fakultas Pertanian, Universitas Lampung. Penelitian ini dilaksanakan pada bulan Februari-Agustus 2017.

Metode penelitian yang digunakan yaitu metode survai. Pemilihan lokasi pembibitan dilakukan secara purposive. Pemilihan kecamatan, desa, dan pemilik kebun tanaman kopi robusta muda dilakukan secara acak bertingkat dan purposive (direkomendasikan). Tanaman kopi robusta muda yaitu tanaman kopi yang berumur kurang dari lima tahun. Posisi geografi, ketinggian tempat, suhu, kadar air, keadaan gulma, jenis vegetasi, dan kegiatan budidaya di lokasi kebun tanaman kopi robusta disajikan pada Tabel 1 .

Sampel tanaman dipilih secara purposive. Pengambilan sampel tanah pada bibit diambil dengan membuka polibag berisi bibit kemudian menuangkan tanah yang berada di dalam polibag ke atas karung dan dipisahkan akar-akar bibit kopi yang tercampur dengan tanah. Akar serabut yang terdapat di pangkal batang bibit tanaman kopi dipotong menggunakan pisau. Pengambilan sampel tanah pada tanaman kopi robusta muda diambil dengan menggunakan tembilang pada kedalaman $0-20 \mathrm{~cm}$. Terdapat 8 titik sub sampel tanah yang posisinya melingkari batang tanaman sampel. Posisi titik sub sampel tanah antara lain empat titik berjarak $10 \mathrm{~cm}$ dan empat titik berjarak $50 \mathrm{~cm}$ dari batang tanaman. Tanah dari ke- 8 titik tersebut kemudian dikompositkan kemudian diambil sebanyak $1 \mathrm{~kg}$. Akar-akar yang terdapat di titik sub sampel tanah dipisahkan kemudian diambil dan dikomposit sebanyak $10 \mathrm{~g}$.

Ekstraksi nematoda dilakukan pada setiap sampel tanah sebanyak $300 \mathrm{cc}$ tanah. Ekstraksi nematoda menggunakan metode penyaringan bertingkat dan sentrifugasi (Hooper, dkk., 2005). Akar yang diekstraksi sebanyak $10 \mathrm{~g}$ akar setiap sampel. Ekstraksi nematoda dari akar menggunakan metode corong Baermann yang dimodifikasi. Suspensi nematoda hasil ekstraksi dari akar dan tanah kemudian difiksasi. Nematoda terlebih dahulu dimatikan dengan cara memanaskan botol yang berisi suspensi tersebut hingga suspensi mencapai suhu $50-70^{\circ} \mathrm{C}$. Suspensi yang telah dijadikan $3 \mathrm{ml}$ ditambah larutan Golden X hingga menjadi $10 \mathrm{ml}$ (Susilo \& Karyanto, 2005).

Perhitungan nematoda dilakukan dengan cara terlebih dahulu mengambil suspensi sebanyak $3 \mathrm{ml}$ dari $10 \mathrm{ml}$ menggunakan pipet tetes kemudian dituang dalam cawan bergaris, dan dihitung di bawah mikroskop stereo binokuler dengan bantuan hand counter. Perhitungan dilakukan hingga suspensi dalam botol suspensi habis. Suspensi hasil fiksasi pada setiap sampel dari akar dan tanah dibuat preparat permanen. Terdapat tiga tahapan dalam pembuatan preparat permanen. Sebanyak 100 nematoda diambil secara acak pada setiap sampel untuk dibuat preparat permanen. Nematoda yang telah dibuat preparat permanen diidentifikasi menggunakan mikroskop Leica ICC50 HD, sampai tingkat takson genus berdasarkan ciri morfologinya pada perbesaran 100 - 400 kali. 
Tabel 1. Karakteristik kebun bibit dan tanaman kopi robusta muda di Kabupaten Tanggamus

\begin{tabular}{|c|c|c|}
\hline $\begin{array}{l}\text { Kecamatan/ } \\
\text { Desa }\end{array}$ & $\begin{array}{l}\text { Pemilik } \\
\text { kebun }\end{array}$ & Karakteristik kebun dan budidaya tanaman \\
\hline $\begin{array}{l}\text { Talang } \\
\text { Padang/ } \\
\text { Sukarame }\end{array}$ & $\begin{array}{c}\text { Kebun } \\
\text { Bibit }\end{array}$ & $\begin{array}{l}\text { Posisi geografis kebun di } 05^{\circ} 21^{\prime} 30,5208^{\prime \prime} \text { LS; } 104^{\circ} 46^{\prime} 42,9276^{\prime \prime} \text { BT; } 230 \text { mdpl. Suhu tanah } \\
26,17^{\circ} \mathrm{C} \text { dan kadar air } 55,71 \% \text {. Tidak terdapat vegetasi atau tanaman penaung yang ditanam di } \\
\text { lokasi kebun bibit dan keadaan gulma di lokasi kebun hanya sedikit. Media tanam bibit yang } \\
\text { digunakan yaitu campuran tanah lapis atas (top soil), pasir yang di ayak, dan kompos (pupuk } \\
\text { kandang) dengan perbandingan 1:1:1. Pengisian media dilakukan sampai batas } 1 \mathrm{~cm} \text { dari bibir } \\
\text { polibag. Penyusunan polibag dilakukan secara teratur. Tiap } 2 \text { atau } 4 \text { polibag disusun satu baris } \\
\text { berselang untuk memudahkan penyiraman dan pengamatan. Penyiraman bibit dilakukan } 3 \text { hari } \\
\text { sekali hingga kapasitas lapang. Jenis pola tanam yaitu monokultur. Pengendalian gulma dilakukan } \\
\text { secara manual. Hama yang menyerang bibit kopi yaitu ulat, jangkrik, belalang, dan kutu. } \\
\text { Pengendalian hama dilakukan secara manual atau menggunakan insektisida dengan bahan aktif } \\
\text { seperti Deltametrin } 25 \mathrm{~g} / 1 \text {, Fenpropatrin } 50 \mathrm{~g} / 1 \text {, Methidation. Penyakit yang menyerang bibit seperti } \\
\text { Rhizoctonia solani Kuhn, Bercak daun Cercospora coffeicola B. Et Cke. Pengendalian penyakit } \\
\text { dilakukan dengan fungisida berbahan aktif Benomil } 50 \% \text {, Mancozeb } 73,8 \% \text { + Karbendazim } 6,2 \% \text {, } \\
\text { dan Copper Oxide } 56 \% \text {. }\end{array}$ \\
\hline $\begin{array}{l}\text { Pulau } \\
\text { Panggung } \\
\text { Gunung } \\
\text { Meraksa }\end{array}$ & $\begin{array}{l}\text { pak } \\
\text { rsusahe }\end{array}$ & $\begin{array}{l}\text { Posisi geografis kebun di } 05^{\circ} 19,684^{\prime} \mathrm{LS} ; 1^{\circ} 43,134^{\prime} \mathrm{BT} ; 359 \mathrm{~m} \mathrm{dpl} \text {, luas kebun } 1 \text { ha. Suhu tanah } \\
24,80^{\circ} \mathrm{C} \text { dan kadar air } 46,47 \% \text {. Tanaman kopi berumur } 3 \text { tahun. Vegetasi } 13 \text { jenis, pola tanam } \\
\text { polikultur. Jenis pupuk yang digunakan yaitu pupuk kandang. Pemupukan dilakukan sebanyak tiga } \\
\text { kali dalam satu tahun. Gulma tergolong sedikit. Pengendalian gulma dilakukan secara fisik } \\
\text { (dikoret). Hama yang menyerang yaitu penggerek batang kopi (PBKo). Pengendalian hama } \\
\text { menggunakan insektisida berbahan aktif Fipronil } 50 \mathrm{~g} / \mathrm{l} \text {. }\end{array}$ \\
\hline $\begin{array}{l}\text { Ulu Belu/ } \\
\text { Ngarip }\end{array}$ & $\begin{array}{l}\text { Bapak } \\
\text { Hermanto }\end{array}$ & $\begin{array}{l}\text { Posisi geografis kebun di } 05^{\circ} 18,826^{\prime} \mathrm{LS} ; 1^{\circ} 32,991^{\prime} \mathrm{BT} \text {; } 845 \text { mdpl, luas kebun } 0,7 \text { ha. Suhu tanah } \\
26,27^{\circ} \mathrm{C} \text { dan kadar air 48,90\%. Umur tanaman kopi } 2,3 \text {, dan } 4 \text { tahun. Vegetasi } 9 \text { jenis, pola tanam } \\
\text { polikultur. Jenis pupuk yang digunakan yaitu NPK Mutiara YaraMila 16-16-16, kompos, dan kulit } \\
\text { kopi. Pemupukan dilakukan sebanyak } 3 \text { kali dalam satu tahun. Gulma tergolong sedikit. } \\
\text { Pengendalian gulma menggunakan herbisida berbahan aktif triclopyr } 100 \mathrm{~g} / \mathrm{L} \text {, fluroxypyr } 75 \mathrm{~g} / \mathrm{L} \text {, } \\
\text { dan clopyralid } 50 \mathrm{~g} / \mathrm{L} \text {. Hama yang menyerang yaitu PBKo dan penggerek batang kopi. } \\
\text { Pengendalian hama dilakukan dengan menggunakan insektisida berbahan aktif dimehipi } 45 \% \text { dan } \\
\text { imidakloprid 3\%. Apabila terdapat tanaman yang mati maka tanaman dipotong kemudian dibuang. }\end{array}$ \\
\hline $\begin{array}{l}\text { Air } \\
\text { Naningan/ } \\
\text { Sinar } \\
\text { Sekampung }\end{array}$ & & $\begin{array}{l}\text { Posisi geografis kebun di } 05^{\circ} 25.457^{\prime} \mathrm{LS} ; 1^{\circ} 69.983^{\circ} \mathrm{BT} ; 340 \mathrm{mdpl} \text {, luas kebun } 1 \text { ha. Suhu tanah } \\
25,89^{\circ} \mathrm{C} \text { dan kadar air } 39,21 \% \text {. Tanaman kopi robusta berumur } 1,5 \text { tahun. Vegetasi berjumlah } 6 \\
\text { jenis, pola tanam polikultur. Jenis pupuk yang digunakan yaitu pupuk kandang, kompos, dan kulit } \\
\text { kopi. Pemupukan dilakukan sebanyak } 3 \text { kali dalam satu tahun. Gulma yang tumbuh sedikit. } \\
\text { Pengendalian gulma secara kimiawi menggunakan herbisida kontak, dan secara fisik (dikoret). } \\
\text { Pengendalian hama menggunakan insektisida berbahan aktif Fipronil } 50 \mathrm{~g} / \mathrm{l} \text {. }\end{array}$ \\
\hline $\begin{array}{l}\text { Sumberejo/ } \\
\text { Sidomulyo }\end{array}$ & Bapak Sigit & $\begin{array}{l}\text { Posisi geografis kebun di } 05^{\circ} 21 \mathrm{LS}^{\prime} ; 104^{\circ} 44^{\prime} \mathrm{BT} ; 337 \mathrm{mdpl} \text {, luas kebun } 1 \text { ha. Suhu tanah } 27,22^{\circ} \mathrm{C} \\
\text { dan kadar air } 27,68 \% \text {. Tanaman kopi berumur } 3 \text { tahun. Vegetasi } 5 \text { jenis, pola tanam polikultur. } \\
\text { Jenis pupuk yang digunakan yaitu pupuk kandang dan Phonska. Pemupukan dilakukan dua kali } \\
\text { dalam satu tahun. Gulma yang tumbuh cukup banyak. Pengendalian gulma menggunakan herbisida } \\
\text { berbahan aktif Isopropilamina Glifosat } 486 \mathrm{~g} / 1 \text {. Tidak ada pengendalian hama dan penyakit } \\
\text { tanaman. Di kebun ini banyak ditemukan semut merah. }\end{array}$ \\
\hline
\end{tabular}

Beberapa spesimen yang tampak bagus difoto menggunakan kamera pada mikroskop yang terhubung dengan komputer. Identifikasi dilakukan enggunakan bantuan buku Goodey (1963), Mai \& Lyon (1975), Smart \& Nguyen (1998), dan referensi pendukung lainnya. Nematoda yang telah diketahui nama genusnya kemudian dikelompokkan ke dalam nematoda parasit tumbuhan dan nematoda hidup bebas.

Pengamatan vegetasi dilakukan dengan cara mengamati semua vegetasi yang tumbuh pada area dua meter ke arah kanan dan dua meter ke arah kiri sepanjang jalur transek arah diagonal kebun. Semua 
jenis tumbuhan dalam jalur ini dicatat dan dihitung jumlah tanamannya. Vegetasi gulma di areal kebun kopi diamati secara visual dan dikelompokkan kedalam banyak atau sedikit. Informasi mengenai kegiatan budidaya tanaman kopi robusta muda diperoleh melalui wawancara langsung dengan petani pemilik kebun dan pengamatan langsung kondisi di kebun.

Pengukuran kadar air tanah dilakukan dengan pengambilan sampel tanah in situ dari tanah komposit seberat 10 gram. Sampel tanah di oven pada suhu 105p C selama 24 jam kemudian ditimbang. Perhitungan kadar air menggunakan rumus :

$$
W=\frac{M w-M p}{M p} \times 100 \%
$$

Keterangan: W: kadar air tanah;

Mw: Bobot tanah basah (10 g);

Mp: Bobot tanah kering

105pC(Susilo \& Karyanto, 2005).

Pengukuran suhu tanah dilakukan dengan menggunakan termometer batang air raksa. Data komunitas nematoda dianalisis untuk menentukan genus nematoda yang dominan menggunakan Prominence Value (PV) genus dengan formula (Beals 1960, dalam Norton 1978) sebagai berikut:

$$
\begin{aligned}
\mathrm{PV} & =\mathrm{KA} \times \sqrt{F A} ; \mathrm{FA} \\
& =\frac{\text { jumla } h \text { sampel mengandung genus } i}{\text { jumla } h \text { seluruh sampel }} \times 100
\end{aligned}
$$

Keterangan: $P V=$ prominance value,

$K A=$ kelimpahan absolut tiap genus dan

$F A=$ frekuensi absolut.

Pengukuran kerusakan tanaman dibedakan antara pengukuran intensitas kerusakan tanaman mutlak (keterjadian) dan pengukuran intensitas kerusakan tanaman relatif(keparahan) tanaman akibat serangan nematoda. Pengukuran keterjadian tanaman akibat serangan nematoda di lokasi kebun bibit dilakukan dengan cara mengamati satu persatu bibit kopi kemudian digolongkan ke dalam tanaman sehat dan tanaman rusak. Pengukuran keterjadian di lokasi kebun tanaman kopi robusta muda dilakukan dengan mengamati tanaman sepanjang jalur transek mengikuti arah diagonal hamparan kebun, kemudian digolongkan ke dalam tanaman sehat dan tanaman rusak. Keterjadian tanaman terserang nematoda dihitung dengan rumus sebagai berikut :

Intensitas kerusakan mutlak

$=\frac{\text { jumlah tanaman rusak }}{\text { seluruh tanaman yang diamati }} \times 100 \%$

Pengukuran keparahan dibedakan antara intensitas kerusakan tanaman relatif(relatif) tajuk dan intensitas kerusakan akar. Intensitas kerusakan relatif di lokasi kebun bibit dilakukan dengan cara mengamati satu per satu setiap bibit dalam polibag kemudian diberi skor berdasarkan tingkat kerusakan yang tampak. Pengukuran intensitas kerusakan letatif di lokasi kebun kopi robusta muda dilakukan sepanjang jalur transek mengikuti arah diagonal hamparan kebun. Setiap tanaman muda yang berada di jalur transek diamati dan diberi skor $0-2$ berdasarkan tingkat kerusakan yang tampak. Tingkat kerusakan relatif terdiri dari tiga kategori yaitu tanaman sehat skor 0 , tanaman rusak sedang skor 1, dan tanaman rusak berat skor 2 .

Pengukuran intensitas kerusakan akar bibit dan tanaman kopi robusta muda ditentukan berdasarkan gejala nekrotik yang tampak akibat serangan nematoda. 
Akar bibit dan tanaman kopi robusta muda terlebih dahulu di cuci, kemudian dipotong dengan panjang 1 $\mathrm{cm}$. Potongan akar diambil secara acak sebanyak 50 potongan kemudian diamati dan diberi skor 0 - 4 . Tingkat kerusakan akar terdiri dari lima kategori yaitu akar sehat skor 0 , rusak ringan skor 1 , rusak sedang skor 2, rusak berat skor 3, dan rusak sangat berat skor 4 (Beaker, 1985). Intensitas kerusakan relatif dan intensitas kerusakan akar dihitung dengan rumus (Beaker, 1985).

$$
\mathrm{IK}=\frac{\sum \text { (ni.vi) }}{\mathrm{N} . \mathrm{V}} \times 100 \%
$$

Keterangan: $\mathrm{IK}=$ Intensitas kerusakan relatif; $\mathrm{ni}=$ jumlah tanaman/akar rusak pada skor vi; $\mathrm{vi}=$ skor tingkat kerusakan ke $\mathrm{i}$; $\mathrm{N}=$ jumlah tanaman/akar yang diamati; $\mathrm{V}=$ skor tertinggi

Data komunitas nematoda dianalisis menggunakan Prominance Value (PV) untuk menentukan genus nematoda parasit tumbuhan yang dominan. Kelimpahan seluruh nematoda dari tanah dan akar, kelimpahan genus nematoda parasit tumbuhan yang dominan dari akar dan tanah, intensitas kerusakan akar, suhu tanah, dan kadar air yang diperoleh dianalisis ragam dan pemisahan nilai tengah diuji Beda Nyata Terkecil (BNT) pada taraf nyata 5\% menggunakan perangkat program SAS (9.1). Hubungan kelimpahan nematoda dari akar dan tanah dengan suhu tanah, kadar air tanah,dan intensitas kerusakan akar, serta hubungan kelimpahan genus nematoda yang dominan dengan kadar air tanah dan intensitas kerusakan akar dianalisis korelasi.

\section{HASIL DAN PEMBAHASAN}

Komunitas Nematoda. Nematoda yang ditemukan di pertanaman kopi robusta di Kabupaten Tanggamus yaitu 38 genus, terdiri dari 16 genus nematoda parasit tumbuhan dan 22 genus nematoda hidup bebas (Tabel 1). Jumlah seluruh genus nematoda dan jumlah genus nematoda parasit tumbuhan serta nematoda hidup bebas dari hasil penelitian ini lebih tinggi daripada jumlah seluruh genus nematoda dan jumlah genus nematoda parasit tumbuhan serta nematoda hidup bebas pada pertanaman kopi monokultur dan agroforestri kopi di Sumberjaya dan pertanaman kopi robusta muda di Tanggamus yang dilaporkan Swibawa, dkk., (2006), Swibawa, dkk., (2009), dan Swibawa, (2014). Pada pertanaman kopi monokultur di Sumberjaya ditemukan 29 genus nematoda, sedangkan pada agroforestri kopi ditemukan 34 genus (Swibawa, dkk., 2006). Jumlah genus nematoda parasit tumbuhan yang ditemukan di pertanaman kopi monokultur di Sumberjaya yaitu 15 genus, sedangkan pada agroforestri kopi ditemukan 12 genus (Swibawa, dkk., 2009). Nematoda yang ditemukan di pertanaman kopi robusta muda di Tanggamus yaitu 20 genus yang terdiri dari 9 genus nematoda parasit tumbuhan dan 11 genus nematoda hidup bebas (Swibawa, 2014).

Kelimpahan Nematoda. Hasil penelitian ini menunjukkan bahwalokasi kebun tidak mempengaruhi kelimpahan nematoda dari tanah, tetapi mempengaruhi kelimpahan nematoda dari akar (Tabel 2). Kelimpahan nematoda dari tanah di setiap lokasi kebun pertanaman kopi robusta tidak berbeda, yaitu berkisar 277- 1039 individu/300 cc tanah. Kelimpahan seluruh nematoda 
Tabel 2. Prominance Value (PV) genus nematoda pada di lima lokasi pertanaman kopi robusta (C. canephora var robusta) di Kabupaten Tanggamus

\begin{tabular}{|c|c|c|c|c|c|c|}
\hline No & Genus & Pulau Panggung & Ulu Belu & Air Naningan & Sumberejo & Kebun Bibit \\
\hline A & Parasit Tumbuhan & & & & & \\
\hline 1 & Pratylenchus & 467,90 & 1115,29 & 122,85 & 511,94 & 14432.76 \\
\hline 2 & Radopholus & 129,81 & 139,17 & 316,66 & 275,96 & 917.71 \\
\hline 3 & Rotylenchulus & 374,00 & 844,01 & 6,34 & 20,63 & 41.82 \\
\hline 4 & Helicotylenchus & 92,82 & 333,54 & 32,08 & 129,31 & 15.56 \\
\hline 5 & Ditylenchus & 97,66 & 50,12 & 82,58 & 104,88 & 215.04 \\
\hline 6 & Gracilacus & 55,34 & 185,46 & 0,00 & 0,00 & 54.1 \\
\hline 7 & Meloidogyne & 0,00 & 0,00 & 58,15 & 0,00 & 163.07 \\
\hline 8 & Paratylenchus & 45,07 & 220,73 & 0,00 & 17,87 & 1634.55 \\
\hline 9 & Rotylenchoides & 4,00 & 9,65 & 0,00 & 12,61 & 0 \\
\hline 10 & Rotylenchus & 0,00 & 0,00 & 7,93 & 0,00 & 53.21 \\
\hline 11 & Tetylenchus & 47,18 & 20,75 & 3,71 & 0,00 & 138.94 \\
\hline 12 & Tylenchorhynchus & 50,71 & 27,12 & 97,05 & 84,04 & 591.83 \\
\hline 13 & Tylenchulus & 0,00 & 0,00 & 0,00 & 88,79 & 1085.54 \\
\hline 14 & Tylenchus & 57,02 & 41,15 & 42,45 & 77,65 & 0 \\
\hline 15 & Xiphinema & 100,59 & 54,40 & 2,97 & 123,68 & 4.35 \\
\hline 16 & Zygotylenchus & 0,00 & 0,00 & 8,26 & 60,57 & 203.37 \\
\hline B & Hidup Bebas & & & & & \\
\hline 17 & Amphidorylaimus & 0,00 & 0,00 & 0,00 & 7,74 & 23.27 \\
\hline 18 & Butterius & 0,00 & 0,00 & 0,00 & 8,35 & 8.71 \\
\hline 19 & Cephalobus & 40,45 & 0,00 & 11,10 & 14,38 & 1064.47 \\
\hline 20 & Cruznema & 0,00 & 0,00 & 9,51 & 36,32 & 13.3 \\
\hline 21 & Cryptonchus & 0,00 & 0,00 & 0,00 & 0,00 & 5.03 \\
\hline 22 & Aphelenchoides & 32,67 & 37,01 & 49,78 & 0,00 & 0 \\
\hline 23 & Aphelenchus & 141,92 & 652,69 & 37,76 & 163,65 & 446.87 \\
\hline 24 & Diploscasterinae & 155,25 & 290,96 & 2,22 & 5,16 & 257.61 \\
\hline 25 & Diplosgasteroides & 0,00 & 0,00 & 0,00 & 17,72 & 15.24 \\
\hline 26 & Dorylaimus & 0,00 & 3,44 & 6,34 & 12,61 & 31.05 \\
\hline 27 & Iotonchus & 0,00 & 0,00 & 5,19 & 34,73 & 55.76 \\
\hline 28 & Mesodorylaimus & 0,00 & 3,44 & 0,00 & 0,00 & 28.31 \\
\hline 29 & Mesorhabditis & 2,48 & 2,18 & 0,00 & 8,86 & 4.7 \\
\hline 30 & Miconchus & 0,00 & 0,00 & 2,97 & 0,00 & 165.74 \\
\hline 31 & Mononchus & 0,00 & 23,55 & 3,71 & 47,78 & 44.69 \\
\hline 32 & Mylonchulus & 0,00 & 0,00 & 2,97 & 12,89 & 387.15 \\
\hline 33 & Pelodera & 6,01 & 31,77 & 82,71 & 74,94 & 460.52 \\
\hline 34 & Rhabditis & 119,22 & 514,03 & 169,77 & 119,90 & 737.2 \\
\hline 35 & Rhabpanus & 8,00 & 13,76 & 82,48 & 82,15 & 26.6 \\
\hline 36 & Rhitis & 0,00 & 0,00 & 0,00 & 0,00 & 235 \\
\hline 37 & Thornonema & 0,00 & 0,00 & 0,00 & 12,61 & 0 \\
\hline 38 & Xylorhabditis & 0,00 & 155,25 & 147,09 & 0,00 & 0 \\
\hline \multicolumn{2}{|c|}{ Jumlah genus } & 20 & 15 & 26 & 28 & 33 \\
\hline
\end{tabular}

Tabel 2. Lanjutan

\begin{tabular}{lccccc}
\hline & Pulau Panggung & Ulu Belu & Air Naningan & Sumberejo & Kebun Bibit \\
\hline Populasi nematoda dari tanah (ind & 395 & 1039 & 277 & 477 & 349 \\
Populasi nematoda dari akar (indi & $134 \mathrm{~b}$ & $165 \mathrm{~b}$ & $78 \mathrm{~b}$ & $98 \mathrm{~b}$ & $535 \mathrm{a}$ \\
\hline
\end{tabular}

Keterangan: tn: tidak nyata pada taraf $\alpha=5 \%$. Nilai tengah dalam baris yang diikuti oleh huruf yang sama dinyatakan tidak berbeda nyata menurut uji BNT pada taraf $\alpha=5 \%$.

dari tanah pada penelitian ini lebih tinggi dibandingkan dengan kelimpahan nematoda dari tanah pada lahan agroforestri kopi dan kopi monokultur di Sumberjaya, yaitu 190 individu/300 ce tanah pada pertanaman kopi agroforestri dan 488 individu/300 cc tanah pada pertanaman kopi monokultur (Swibawa, dkk., 2006). 
Kelimpahan seluruh nematoda dari akar di Kebun Bibit lebih tinggi daripada di Pulau Panggung, Air Naningan, Ulu Belu, dan Sumberejo, tetapi kelimpahan seluruh nematoda dari akar di Pulau Panggung, Air Naningan, Ulu Belu, dan Sumberejo tidak berbeda (Tabel 2). Hal ini diduga disebabkan media kompos (pupuk kandang) yang digunakan untuk pembibitan di Kebun Bibit dan penyiraman yang teratur sehingga kondisi kadar air tanah optimum bagi perkembangan nematoda. Hasil analisis korelasi menunjukkan bahwa kadar air berkorelasi positif dengan kelimpahan seluruh nematoda dari akar dengan $r=0,62$. Dengan demikian dapat dikatakan bahwa tingginya kelimpahan nematoda dari akar di pembibitan dipengaruhi oleh kadar air tanah.

Berdasarkan Prominance Value (PV) lima genus nematoda parasit tumbuhan yang dominan adalah Pratylenchus, Rotylenchulus, Radopholus, Helicotylenchus, dan Ditylenchus (Tabel 2). Kelima genus nematoda parasit tumbuhan tersebut ditemukan di semua lokasi kebun pertanaman kopi. Nilai PV yang tinggi suatu genus menunjukkan bahwa genus tersebut dominan dalam komunitasnya. Hasil penelitian ini sejalan dengan hasil penelitian Swibawa (2014) yang menyatakan bahwa Pratylenchus dan Radopholus merupakan genus nematoda yang dominan penting pada pertanaman kopi muda di Kabupaten Tanggamus. Wiryadiputra \& Trans (2008) dalam Swibawa (2014) juga melaporkan bahwa terdapat tiga nematoda parasit tumbuhan yang penting pada pertanaman kopi robusta di Lampung yaitu Pratylenchus, Meloidogyne, dan Rotylenchulus dari sekitar 10 genus nematoda parasit tumbuhan yang ditemukan pada pertanaman kopi di Indonesia. Menurut Sauza(2000), salah satu nematoda parasit tumbuhan yang berasosiasi dengan tanaman kopi di Indonesia yaitu Ditylenchus dipsaci, Helicotylenchus dihystera, dan Rotylenchulus reniformis. Selain itu Trinh, ddk., (2009) melaporkan bahwa Rotylenhculus, Meloidogyne, Pratylenchus, Radopholus, Helycotylenchus, dan Xiphinema menyerang pertanaman kopi di Vietnam. Menurut Whitehead (1968) dalam Campos \& Villain (2005) $R$. reniformis terdapat pada bibit tanaman kopi di tempat pembibitan yang komersial di Brazil. Nematoda R. reniformis ditemukan di pertanaman kopi di Papua Nugini, Fiji, Tonga dan Samoa Barat (Bridge, 1988 dalam Campos \& Villain, 2005). Dengan demikian, genus nematoda yang ditemukan dalam penelitian ini sama dengan yang dilaporkan oleh peneliti yang lain.

Hasil penelitian ini menunjukkan bahwa Pratylenchus, Rotylenchulus, Radopholus, Helicotylenchus, dan Ditylenchus dominan di lima lokasi kebun pertanaman kopi robusta di Tanggamus. Kelimpahan nematoda parasit tumbuhan dominan terutama Rotylenchulus dari tanah dan Pratylenchus dari akar antar lokasi berbeda, akan tetapi kelimpahan nematoda yang lain tidak berbeda (Tabel 3). Kelimpahan Pratylenchus yaitu 321 individu/300 cc tanah di kebun bibit dalam penelitian ini lebih tinggi dibandingkan kelimpahan Pratylenchus di Vietnam yaitu 124 individu/250 ml tanah (Trinh, ddk., 2009). Kelimpahan Pratylenchus dan Radopholus di Air Naningan dan Sumberejo dalam penelitian ini lebih rendah dibandingkan hasil yang dilaporkan Swibawa 
Tabel 3. Kelimpahan lima genus nematoda parasit tumbuhan yang dominan dalam tanah dan akar pertanaman kopi robusta (C. canephora var robusta) di lima lokasi kebun di Tanggamus

\begin{tabular}{|c|c|c|c|c|c|c|c|}
\hline & Genus & Kebun Bibit & $\begin{array}{c}\text { Pulau } \\
\text { Panggung }\end{array}$ & Ulu Belu & Air Naningan & Sumberejo & F hitung \\
\hline \multirow{2}{*}{ Pratylenchus } & $\begin{array}{l}\text { Tanah (individu/300 } \\
\text { cc tanah) }\end{array}$ & 58 & 54 & 190 & 13 & 64 & $1,65 \mathrm{tn}$ \\
\hline & $\begin{array}{l}\text { Akar (individu/10 g } \\
\text { akar) }\end{array}$ & $321 \mathrm{a}$ & $40 \mathrm{~b}$ & $33 b$ & $8 \mathrm{~b}$ & $8 \mathrm{~b}$ & $6,18 *$ \\
\hline \multirow{2}{*}{ Rotylenchulus } & $\begin{array}{l}\text { Tanah (individu/300 } \\
\text { cc tanah) }\end{array}$ & $11 \mathrm{bc}$ & $89 a b$ & $239 \mathrm{a}$ & $3 \mathrm{c}$ & $10 \mathrm{bc}$ & $3,90 *$ \\
\hline & $\begin{array}{l}\text { Akar (individu/10 g } \\
\text { akar) }\end{array}$ & 0 & 3 & 0 & 0 & 0 & $1 \mathrm{tn}$ \\
\hline \multirow{2}{*}{ Radopholus } & $\begin{array}{l}\text { Tanah (individu/300 } \\
\text { cc tanah) }\end{array}$ & 20 & 29 & 28 & 48 & 57 & $0,45 \mathrm{tn}$ \\
\hline & $\begin{array}{l}\text { Akar (individu/10 g } \\
\text { akar) }\end{array}$ & 65 & 8 & 12 & 15 & 11 & $0,79 \mathrm{tn}$ \\
\hline \multirow{2}{*}{ Helicotylenchus } & $\begin{array}{l}\text { Tanah (individu/300 } \\
\text { cc tanah) }\end{array}$ & 4 & 26 & 94 & 11 & 27 & $2,38 \mathrm{tn}$ \\
\hline & $\begin{array}{l}\text { Akar (individu/10 g } \\
\text { akar) }\end{array}$ & 0 & 0 & 0 & 0 & 5 & $1 \mathrm{tn}$ \\
\hline \multirow{2}{*}{ Ditylenchus } & $\begin{array}{l}\text { Tanah (individu/300 } \\
\text { cc tanah) }\end{array}$ & 16 & 17 & 0 & 23 & 30 & $2,88 \mathrm{tn}$ \\
\hline & $\begin{array}{l}\text { Akar (individu/10 g } \\
\text { akar) }\end{array}$ & 3 & 11 & 14 & 0 & 0 & $2,67 \mathrm{tn}$ \\
\hline
\end{tabular}

Keterangan : tn: tidak nyata pada taraf $\alpha=5 \%$. Nilai tengah dalam baris yang diikuti oleh huruf yang sama dinyatakan tidak berbeda nyata menurut uji BNT pada taraf $\alpha=5 \%$.

(2014). Kelimpahan Pratylenchus di Air Naningan dan Sumberejo yaitu 184,1 individu/300 cc tanah dan 421,7 individu/300 cc tanah, sedangkan kelimpahan Radopholus di Air Naningan dan Sumberejo yaitu 123,5 individu/300 cc tanah dan 846,5 individu/300 cc tanah (Swibawa, 2014).
Kerusakan tanaman. Intensitas kerusakan tanaman mutlak (keterjadian) pada pertanaman kopi robusta berkisar $27-61 \%$ (Tabel 4). Intensitas kerusakan tanaman relatif (keparahan) tajuk di lima kebun pertanaman kopi robusta berkisar 11,78 40,91\% dengan intensitas kerusakan akar berkisar 35

Tabel 4. Intensitas kerusakan mutlak, intensitas kerusakan akar dan intensitas kerusakan relatif tanaman kopi di lima lokasi pertanaman kopi robusta (C. canephora var robusta) di Tanggamus

\begin{tabular}{|c|c|c|c|}
\hline Desa & Intensitas kerusakan mutlak & Intensitas kerusakan akar & Intensitas kerusakan relatif \\
\hline & & ….......\%.......... & \\
\hline Talang Padang (Kebun Bibit) & 27 & 69,20 & 11,78 \\
\hline Pulau Panggung & 48 & 35,00 & 28,57 \\
\hline Ulu Belu & 32 & 48,17 & 19 \\
\hline Air Naningan & 61 & 46,67 & 40,91 \\
\hline Sumberejo & 42 & 46,67 & 24 \\
\hline F hitung & & $3,35 \mathrm{tn}$ & \\
\hline
\end{tabular}

Keterangan: tn: tidak nyata pada taraf $\alpha=5 \%$. 
$-69,20 \%$ (Tabel4). Hal ini menunjukkan bahwa sudah ada $27-61 \%$ tanaman kopi yang menunjukkan gejala kerusakan akibat serangan nematoda, dengan intensitas kerusakan tanaman relatif (keparahan) rusak berat. Menurut Wiryadiputra (2014) bahwa batas ambang toleransi kerusakan karena infeksi nematoda adalah 5\%. Tingkat kerusakan tanaman mutlak (keterjadian) sudah menunjukkan lebih dari 5\%, sehingga sudah di atas ambang toleransi. Keadaan ini cukup parah, sehingga harus dilakukan pengendalian. Hasil analisis korelasi menunjukkan bahwa korelasi tingkat kategori kerusakan tanaman dengan intensitas kerusakan akar tidak nyata dengan $r=0,545$. Dengan demikian dapat dikatakan bahwa tingginya intensitas kerusakan akar tidak menggambarkan tingginya intensitas kerusakan tanaman relatif(keparahan) tajuk. Terdapat korelasi positif antara intensitas kerusakan akar dengan kelimpahan nematoda dari akar $\left(\mathrm{r}=0,808^{*}\right)$. Dengan demikian dapat dikatakan bahwa tingginya intensitas kerusakan akar dipengaruhi oleh kelimpahan nematoda dari akar. Hasil analisis korelasi menunjukkan bahwa kelimpahan Pratylenchus dan Radopholus dari akar berkorelasi positif dengan intensitas kerusakan akar dengan $r=0,568$ dan $r=0,733$. Dengan demikian, intensitas kerusakan akar pada bibit dan tanaman kopi robusta muda kemungkinan disebabkan serangan Pratylenchus dan Radopholus secara bersama-sama. Serangan Pratylenchus dan Radopholus secara bersama-sama dapat menimbulkan kerusakan akar yang lebih parah (Swibawa, 2014).

\section{KESIMPULAN}

Berdasarkan penelitian dapat disimpulkan bahwa ditemukan 38 genus nematoda yang terdiri dari 16 genus nematoda parasit tumbuhan dan 22 genus nematoda hidup bebas. Genus nematoda parasit tumbuhan yang dominan pada bibit dan tanaman kopi robusta muda yaitu Pratylenchus, Radopholus, Rotylenchulus, Helicotylenchus, dan Ditylenchus. Kelimpahan Pratylenchus pada bibit dan kopi robusta muda yaitu 13 - 190 individu/300 cc tanah dan 321 individu/10 g akar di kebun bibit. Intensitas kerusakan tanaman mutlak (keterjadian) dan kerusakan tanaman relatif(keparahan) bibit yaitu 27\% dan 11,8\% dengan intensitas kerusakan akar 69,20\%. Intensitas kerusakan tanaman mutlak (keterjadian) dan kerusakan tanaman relatif (keparahan) tanaman kopi muda berkisar $32-61 \%$ dan $19-24 \%$ dengan intensitas kerusakan akar berkisar 35 - 48,17\%.

\section{SANWACANA}

Dalam penelitian ini penulis mendapatkan bantuan dana penelitian dari magenemen PT Nestle Indonesia dan bantuan dari agri servise Nestle serta petani pemilik kebun. Dalam kesempatan ini diucapkan terimakasih.

\section{DAFTAR PUSTAKA}

Badan Pusat Statistik Provinsi Lampung. 2013. Lampung Dalam Angka 2013. BPS. Bandar Lampung. 
Beaker, K. R. 1985. Nematode Ekstraction and Bioassays. Pp. 19-38. In: An AdvanceTrasise on Meloidogyne Vol II. K. R. Barker, C. C. Caster, \& J. N. Sasser. (eds). North Caroline State University Press.

Campos, V. P. \& L. Villain. 2005. Nematode Parasites of Coffee and Cocoa. Pp. 529-580. In: Plant Parasitic Nematodes in Subtropical and Tropical Agriculture. M. Luc., R. A. Sikora, \& J. Bridge (eds). CABI Publishing. UK.

Direktorat Jenderal Perkebunan. 2016. Statistik Perkebunan Indonesia 2015-2017. Direktorat Jendral Perkebunan, Jakarta.

Goodey, J. B. 1963. Soil and Fresh Water Nematodes. Butler and Tunner, London.

Hooper, D. J., J. Hallman, \& S. A. Subbotin. 2005. Methods for Extraction, Processing and Detection of Plant and Soil Nematodes. Pp. 53-86. In: Plant Parasitic Nematodes in Subtropical and Tropical Agriculture. M. Luc, R, A, Sikora \& J. Bridge (eds). CABI Publishing. UK.

Keputusan Menteri Pertanian. 2004. Pelepasan Kopi Robusta Klon Bp 308 Sebagai Varietas/Klon Unggul. Kementrian Pertanian. Jakarta

Mai, W. F., \& H. H. Lyon. 1975. Key to Genera of Plant Parasitic Nematodes. Cornell University, London.

Mc Sorley. R. 2009. Soil-inhabiting Nematodes. University ofFlorida. http://entnemdept.ufl.edu/ creatures/nematode/soil_nematode.htm. Diakses pada 03 Januari 2017.
Mustika, I. 2010. Konsepsi dan strategi pengendalian nematoda parasit Tanaman di Indonesia. Pengembangan Inovasi Pertanian. 3(2): 81101

Norton, D.C. 1978. Ecology of Plant Parasitic Nematodes. John Willey and Sons, New York, Chichester, Brisbane, and Toronto.

Sauza, R. M. 2000. Plant-Parasitic Nematodes of Coffee. Universidade Estadual do Norte Fluminense Darcy Ribeiro, Brazil.

Smart, G. C. \& K. B. Nguyen. 1988. Illustrated Key for the Identification of Common Nematodes in Florida. University of Florida, Florida.

Susilo, F. X. \& A. Karyanto. 2005. Methods for Assessment of Below-Ground Biodiversity in Indonesia. Universitas Lampung, Bandar Lampung.

Swibawa, I. G., T. N. Aeny, I. Mashyuda, F. X. Susilo, \& K. Hairiah. 2006. Alih guna lahan hutan menjadi lahan pertanian: Keragaman dan kelimpahan nematode. Jurnal Agrivita. 28(3): 252-266.

Swibawa, I. G., R. Evrizal, F. K. Aini, F. X. Susilo, K. Hairiah, \& Suprayogo. 2009. Penurunan keragaman pohon dan nematoda akibat alih guna hutan menjadi lahan pertanian memacu munculnya masalah nematoda. Prosiding. Seminar "Peranan konservasi flora indonesia dalam mengatasi dampak pemanasan global. Bali, 14 Juli 2009. 
Swibawa, I G. 2014. Komunitas nematoda pada tanaman kopi (Coffea canephora var robusta) muda di Kabupaten Tanggamus Lampung. Jurnal Agrotrop. 4(2): 139147.

Trinh, P. Q., E. D. L. Pena., C. N. Nguyen, H. X. Nguyen, \& M. Moens. 2009. Plantparasitic nematodes associated with coffee in Vietnam. Russian Journal of Nematology. 17(1): 73-82.

Wiryadiputra, S. 2014. Evaluasi Tanaman Kopi Asal Bibit dari Puslitkoka Kerjasama dengan Nestle di Kabupaten Tanggamus, Lampung. Laporan Kunjungan, Lampung.

Yeates, G.W., T. Bongher, R. G. M. De Goe, D. W. Freckman, \& S. S. Georgieva. 1993. Feeding habits in soil nematode families and genera - an outline for soil ecologists. Journal of Nematology. 25(3): 315-331. 